\title{
Pengaruh Disruptive Innovation Terhadap Pendidikan Di Akademi Militer Pada Era Society 5.0
}

\section{(Influence Of Disruptive Innovation On Education In The Military Academy In The Society 5.0 Era)}

\author{
Muhammad Irfan ${ }^{1}$, Agustina Dwi MP ${ }^{2 *}$, Novega Galih Armyanto ${ }^{3}$, \\ Raihan Muhammad Rifqi ${ }^{4}$, Satria Nawal Azka ${ }^{5}$, Muhammad Abdul Ghofur ${ }^{6}$ \\ 1,2, 3, 4, 5 Prodi Teknik Elektronika Pertahanan Akademi Militer \\ 6 Prodi Teknik Aeronautika Pertahanan Akademi Angkatan Udara \\ E-mail: Irfanfreecss@gmail.com, Athenamahanipuna@akmil.ac.id, Galih47army@gmail.com, \\ raihanrifqi9@gmail.com, Nawalazka40@gmail.com,m_abdulghofur@aau.ac.id
}

\begin{abstract}
Increasing Military Academy as an educational institution must be able to receive the era of 5.0 societies properly. This educational institution has the best way to take the advantage of disruptive innovations among others is to integrate disruptive innovation in learning methods that provide the ability to deal with complex problems and utilize the latest technology to improve the quality of students effectively and efficiently.
\end{abstract}

Keywords— The era of societies 5.0, Disruptive Innovative and Military Academy

Abstrak- Akademi Militer sebagai lembaga pendidikan harus mampu menyambut era society 5.0 dengan baik. Cara terbaik Akademi Militer dalam memanfaatkan inovasi disruptif di era society 5.0 adalah dengan mengintegrasikan inovasi disruptif didalam metode belajar yang dapat memberikan kemampuan menghadapi permasalahan kompleks dan memanfaatkan teknologi terkini dalam rangka meningkatkan kualitas peserta didik secara efektif dan efisien.

Kata Kunci- Era Society 5.0, Inovasi Disruptif, Akademi Militer

\section{Pendahuluan}

Dendidikan memiliki peranan penting dalam meningkatkan kualitas sumber daya manusia dalam mengimbangi perkembangan teknologi yang ada. Seiring perkembangan zaman, tentu kebutuhan manusia akan bertambah oleh karena itu pendidikan secara terus-menerus mengalami perubahan dalam kurikulumnya. Perubahan yang secara umum terjadi pada kurikulum pendidikan yang dialami suatu negara seperti media belajar, metode pengajaran, evaluasi hasil belajar, dan sebagainya. Jika hal ini ditangani dengan tepat maka suatu negara akan memiliki sumber daya manuusia yang mampu menerapkan pemikiran logis, kritis, sistematis, dan inovatif. Sehingga mempengaruhi kesejahteraan kehidupan penduduk yang ada di negara tersebut.Seiring dengan perkembangan teknologi yang berkembang pesat dan bergerak maju, maka teori-teori pun terus berkembang mengikutinya. Dinamika pergerakan tersebut terus bergerak pada laju yang sulit hentikan. Peradaban kehidupan umat manusia telah berada pada fase dimana teknologi informasi telah menembus segala aspek kehidupan manusia.

* Penulis Korespondensi (Agustina Dwi MP)

E-mail: athenamahanipuna@akmil.ac.id 
Perkembangan setelah itu, memasuki era society 5.0 dimana manusia sebagai komponen utama memiliki nilai-nilai baru dalam perkembangan teknologi sehingga sistem pendidikan telah berubah seiring dengan berlangsungnya proses globalisasi dan banyaknya temuan baru dibidang teknologi komunikasi dan informasi. Kondisi pendidikan sangat dipengaruhi oleh berbagai fenomena yang muncul setelah melewati perkembangan teknologi dan informasi. Sistem pendidikan saat ini telah memasuki suatu orbit baru yang disebutnya sebagai orbit inovasi disruptif. Pada orbit ini menuntut akan keunggulan kreasi dan inovasi lebih dominan. Akademi Militer sebagai penyelenggara pendidikan pertama pembentukan perwira TNI-AD memiliki kewajiban menyiapkan seorang prajurit yang memiliki kemampuan beradaptasi dalam perkembangan teknologi informasi dan tetap menjunjung tinggi kultur dasar kemiliteran yang disiplin, militan, dan loyal terhadap Bangsa dan Negara Indonesia. Oleh karena itu perkembangan dan kemajuan teknologi dan informasi menuntut institusi Pendidikan dalam hal ini Akademi Militer untuk lebih kreatif dan inovatif dalam metode pendidikan yang dimilikinya, dalam rangka mengoptimalkan kualitas dari sumber daya manusia yang diharapkan menjadi seorang perwira yang profesional dan berkarakter. Dalam mengantisipasi era society 5.0, Akademi Militer perlu menata ulang strategi pendidikan dengan melakukan kajian terhadap tujuan strategis lembaga yang didasarkan atas kebutuhan TNI-AD dan juga melakukan evaluasi yang intens (terus menerus secara mendalam) terhadap kompetensi internal lembaga itu sendiri, termasuk dalam hal ini melakukan penilaian kinerja pendidikan.

\section{LANDASAN TEORI}

\section{A. Pengertian Inovasi Desruptive}

Inovasi disruptif atau disruptive innovation adalah inovasi yang membantu menciptakan pasar baru, mengganggu atau merusak pasar yang sudah ada, dan pada akhirnya menggantikan teknologi terdahulu tersebut (Christensen dan Bower, 1995). Inovasi Disruptif ini biasanya mengambil segmen pasar tertentu yang kurang diminati atau dianggap kurang penting bagi penguasa pasar, namun inovasinya bersifat breakthrough dan mampu meredefinisi sistem atau pasar yang eksis. Munculnya Inovasi Disruptif jika tidak diantisipasi dengan baik oleh dunia usaha dapat menyebabkan kejatuhan. (Hadad, 2017). Inovasi disruptif, dalam bahasa Indonesia yang disadur bebas berarti inovasi yang mengacau atau inovasi yang mengganggu. Kata mengganggu pada konteks ini tidak dapat diambil maknanya secara bebas begitu saja. Sejalan dengan perkembangan teknologi, mengganggu dalam konteks ini bermakna bahwa munculnya inovasi teknologi baru akan mengganggu keberadaan teknologi yang lama. Banyak contoh yang ada, misalkan dalam hal pendidikan, kini pembelajaran hampir seluruhnya dilaksanakan secara daring, terlepas dari kondisi pandemi, perubahan ini cukup memperlihatkan dampak dari inovasi disruptif. Contoh lain misalnya buku bacaan tampil dalam bentuk e-book.

Edi Suandi Hamid (2017: 3) menegaskan berbagai fenomena yang ada tersebut sudah jelas terjadi bukan tanpa sebab. Pertama, perkembangan teknologi memiliki pengaruh yang sangat besar terhadap arah perubahan dan inovasi. Kedua, kebutuhan yang tinggi akan efisiensi dan efektifitas menyebabkan produsen perlu melakukan inovasi yang memadahi. Pada tataran ini dapat dikatakan bahwa pepatah mengatakan "tidak ada asap jika tidak ada api" berlaku dalam konteks munculnya pelaku baru dengan berbagai inovasi. Kebutuhan akan efisiensi merupakan sebab yang kuat bagaimana produsen harus melakukan inovasi untuk masuk ke dalam pasar. Inovasi yang mengganggu ini terjadi di berbagai belahan dunia dan dalam berbagai aspek kehidupan mulai dari ekonomi, transportsi, dan lain sebagainya. Inovasi disruptif juga terjadi pada aspek pendidikan, ditandai dengan munculnya kursus kursus secara online sampai sebuah kelas akan menjadi rombongan belajar yang terhimpun dalam grup di media sosial. Pengajar dapat dengan mudah menyampaikan materi melalui media tersebut. Hadirnya kursus atau kelas 
online melalui teleconference menjadikan jarak bukan permasalahan lagi. Kini buku tidak lagi berbentuk tumpukan kertas, e-book yang lebih efektif dan efisien hadir menggantikannya.

Selain menciptakan produk baru konsep disruptive innovation juga membuat konsumen mendapatkan layanan yang lebih efektif dan efisien. Berbagai inovasi membuat konsumen pendidikan lebih mudah dalam mengakses keperluan pendidikan. Salah satu contohnya adalah pendaftaran sekolah atau perguruan tinggi yang menggunakan sistem online. Dalam pelaksanaan seleksi atau ujian pun kini tidak lagi menggunakan kertas, namun dengan sistem Computer Based Test.Memiliki motto Center of Excellence, Akademi Militer sebagai lembaga pendidikan pertama pencetak perwira TNI-AD juga terkena dampak dari inovasi disruptif. Dalam pendaftaran seleksi calon taruna menggunakan sistem online, sehingga peserta seleksi lebih mudah dalam mengakses dan pendataan oleh penyelenggara pun lebih efektif. Teknologi juga masuk dalam pelaksanaan seleksi, komputer menjadi sarana utama untuk pengerjaan soal ujian. Sehingga dalam pengoreksian maupun pemeringkatan peserta seleksi lebih akurat. Inovasi disruptif di Akademi Militer terjadi dalam berbagai aspek pendidikan. Kini menembak tidak lagi harus dilakukan di lapangan tembak, dengan adanya simulasi menembak menggunakan recoil dop laser peserta didik tetap dapat melatih kemampuan menembaknya. Dalam taktik tempur Akademi Militer memiliki augmented reality sandbox, di mana ARES ini lebih variatif dan membuat gambaran medan sebenarnya lebih jelas. GPS juga merupakan salah satu perwujudan dari inovasi disruptif, di mana secara nyata mempermudah dalam pelaksanaan pembelajaran navigasi darat. Bagi Akademi Militer inovasi disruptif tidak akan membuat kedisiplinan dan loyalitas luntur, namun memajukan pemikiran dan kemampuan sehingga dalam pelaksanaan pendidikan diharapkan dapat memberi hasil yang maksimal.

\section{B. Pengertian Era Society 5.0}

Sudah sejak lama masyarakat mengenal era revolusi industry 4.0 dimana banyak hal dikendalikan oleh internet atau yang dikenal dengan IoT. Tetapi kini, telah muncul pengembangan dari era revolusi industri 4.0 yaitu era society 5.0. Era Society 5.0 adalah suatu konsep masyarakat yang berpusat pada manusia (human-centered) dan berbasis teknologi (technology based) yang dikembangkan oleh Jepang. Konsep ini lahir sebagai pengembangan dari revolusi industri 4.0 yang dinilai berpotensi mendegradasi peran manusia. Gagasan tentang "Masyarakat 5.0," dijelaskan sebagai masyarakat masa depan yang dipandu oleh ilmu pengetahuan dan teknologi inovasi dengan menerapkan inisiatif menggabungkan ruang fisik (dunia nyata) dan dunia maya dengan memanfaatkan TIK sepenuhnya, bertujuan membentuk masyarakat ideal di masa depan, yaitu "super smart people " atau masyarakat yang membawa manfaat bagi orang-orang (Deguchi dkk, 2020)

Diawali dengan Society 1.0 yang didefinisikan sebagai kelompok manusia yang berburu dan meramu dalam hidup berdampingan secara harmonis dengan alam, kemudian Society 2.0 sebagai kelompok pembentuk yang berbasis pada budidaya pertanian, peningkatan organisasi dan pembangunan bangsa, Society 3.0 adalah masyarakat yang mempromosikan industrialisasi melalui Revolusi Industri, memungkinkan produksi massal, dan Society 4.0 sebagai masyarakat informasi yang mewujudkan peningkatan nilai tambah dengan menghubungkan aset tidak berwujud sebagai jaringan informasi. Society 5.0 adalah masyarakat informasi yang dibangun di atas Society 4.0, yang bertujuan untuk masyarakat sejahtera yang berpusat pada manusia.

Konsep masyarakat yang berpusat pada manusia dan berbasis teknologi dimaksudkan agar dalam pelaksanaannya artificial intelligence tidak menggantikan keberadaan manusia. Di mana pada masyarakat era Society 5.0, teknologi AI dan IoT berfungsi sebagai pengolah data dan menganalisis data yang bersumber pada manusia itu sendiri melalui sensor fisik atau berupa data pada manusia itu sendiri. Kemudian sensor atau data tersebut lalu mengumpanbalikkan data yang telah di proses oleh AI dan IoT kembali ke manusia dengan berbagai bentuk fisik. Hubungan manusia dan alam nyata kini terhubung erat dengan alam maya (big data, IoT dan AI ) sebagai suksesi kemudahan dan kebutuhan manusia dalam hidup. 
Masyarakat 5.0 lebih menekankan pada manusia sebagai elemen utamanya (human centered), yaitu kehidupan manusia akan lebih baik ketika teknologi berperan sebagai penyempurna kemudahan dalam hidup sehari-hari. Termasuk meminimalisir kesenjangan sosial untuk daerah- daerah yang sulit terjangkau akses jalan, transportasi, medis, dan lain sebagainya. Termasuk dalam pendidikan, teknologi sangat diperlukan dalam mendukung perkembangan pendidikan. Selain mempermudah pelaksanaan pekerjaan, teknologi juga membuat hasil menjadi lebih maksimal. Waktu yang digunakan akan lebih sedikit dan pengerjaan menjadi lebih efektif, hal itu akan berjalan dengan baik apabila manusia tetap menjadi pelaku utamanya.

Keberadaan Society 5.0 pasti memiliki dampak positif maupun negatif. Dampak positif pastilah sesuai dengan cita dari diciptakannya konsep masyarakat ini, yaitu teknologi sebagai upaya kemudahan pemenuhan kebutuhan manusia di masyarakat dalam berbagai bidang. Namun jika berbicara dampak negatif, tentunya yang dikhawatirkan adalah akan terjadi penggeseran keberadaan manusia dan pekerjaannya. Di mana, pengiriman sudah tidak lagi menggunakan jasa manusia, asisten rumah tangga yang sudah dikerjakan oleh robot, supir yang sudah bisa digantikan dengan transportasi otomatis (tanpa supir), kasir yang sudah digantikan mesin penghitung barang belanjaan, teller bank yang sudah digantikan dengan mesin ATM setor/ambil, hingga proses pembedahan (operasi) pun bisa dilakukan dengan baik oleh robot.

Ketika teknologi dan sumber daya manusia bisa sama sama berkembang maka akan dihasilkan keadaan yang menguntungkan, yaitu membentuk masyarakat ideal di masa depan, masyarakat super cerdas. Masyarakat super cerdas dicirikan sebagai berikut: masyarakat di mana berbagai kebutuhan masyarakat dibedakan dan dipenuhi dengan menyediakan produk dan layanan yang diperlukan dalam jumlah yang dibutuhkan kepada orang-orang yang membutuhkannya saat mereka membutuhkannya, dan di mana semua orang dapat menerima layanan berkualitas tinggi dan menjalani kehidupan yang nyaman dan penuh semangat yang memungkinkan berbagai perbedaan mereka seperti usia, jenis kelamin, wilayah, atau bahasa. Disebut demikian untuk menunjukkan masyarakat baru yang diciptakan oleh transformasi yang dipimpin oleh inovasi ilmu pengetahuan dan teknologi, mengikuti masyarakat pemburu, masyarakat agraris, masyarakat industri, dan masyarakat informasi.

\section{Pengertian Pendidikan}

Menurut Aristoteles, Education is a function of the State, and is conducted, primarily at least, for the ends of the State. State - highest social institution which secures the highest goal or happiness of man. Education is preparation for some worthy activity. Education should be guided by legislation to make it correspond with the results of psychological analysis, and follow the gradual development of the bodily and mental faculties. Artinya : Pendidikan adalah salah satu fungsi dari suatu negara, dan dilakukan, terutama setidaknya, untuk tujuan Negara itu sendiri. Negara adalah institusi sosial tertinggi yang mengamankan tujuan tertinggi atau kebahagiaan manusia. Pendidikan adalah persiapan/bekal untuk beberapa aktivitas/pekerjaan yang layak. Pendidikan semestinya dipandu oleh undang-undang untuk membuatnya sesuai (koresponden) dengan hasil analisis psikologis, dan mengikuti perkembangan secara bertahap, baik secara fisik (lahiriah) maupun mental (batiniah/jiwa).

Menurut Scocrates,Pendidikan adalah suatu sarana yang digunakan untuk mencari kebenaran. Sedangkan metode-nya adalah dialektika. Menurut Undang - Undang, UU SISDIKNAS No. 2 tahun 1989: Pendidikan adalah usaha sadar untuk menyiapkan peserta didik melalui kegiatan bimbingan, pengajaran, dan latihan bagi peranannya di masa yang akan datang. UU SISDIKNAS no. 20 tahun 2003: Pendidikan adalah usaha sadar dan terencana untuk mewujudkan suasana belajar dan proses pembelajaran agar peserta didik secara aktif mengembangkan potensi dirinya untuk memiliki kekuatan spiritual keagamaan pengendalian diri, kepribadian, kecerdasan, akhlak mulia, serta keterampilan yang diperlukan dirinya dan masyarakat. 
Menurut Etimologi ( Bahasa ) Pendidikan dalam Islam,Dalam Bahasa Arab Pendidikan : berasal dari kata Tarbiyah, dengan kata kerja Rabba yang memiliki makna mendidik atau mengasuh. Jadi Pendidikan dalam Islam adalah Bimbingan oleh pendidik terhadap perkembangan jasmani, rohani dan akal anak didik sehingga bisa terbentuk pribadi muslim yang baik. Dalam Bahasa Yunani: Pendidikan berasal dari kata Pedagogi, yaitu dari kata "paid" artinya anak dan "agogos" artinya membimbing. Itulah sebabnya istilah pedagogi dapat diartikan sebagai "ilmu dan seni mengajar anak (the art and science of teaching children).

\section{Pengertian Pengaruh}

Menurut Kamus Besar Bahasa Indonesia pengertian pengaruh adalah daya atau timbul dari sesuatu (orang, benda) yang ikut membentuk watak, kepercayaan atau perbuatan seseorang.

Pengertian pengaruh menurut beberapa ahli yaitu:

1. Menurut Wiryanto, pengaruh adalah tokoh formal dan informal di masyarakat yang memiliki ciri-ciri kosmopolitan, inovatif, kompeten, dan aksesibel dibandingkan dengan pihak yang dipengaruhi.

2. Menurut M. Suyanto, pengaruh adalah nilai kualitas suatu iklan melalui media tertentu.

3. Menurut Uwe Becker, pengaruh adalah kemampuan yang terus berkembang dan tidak terlalu terkait dengan usaha memperjuangkan dan memaksakan kepentingan.

4. Menurut Norman Barry, pengaruh adalah suatu tipe kekuasaan agar bertindak dengan cara tertentu, terdorong untuk bertindak demikian, sekalipun ancaman sanksi yang terbuka tidak merupakan motivasi yang mendorongnya.

5. Menurut Robert Dahl, pengaruh diumpamakan sebagai berikut: A mempunyai pengaruh atas B sejauh ia dapat menyebabkan B untuk berbuat sesuatu yang sebenarnya tidak akan B lakukan.

6. Menurut Sosiologi Pedesaan, pengaruh adalah kekuasaan yang bisa mengakibatkan perubahan perilaku orang atau kelompok lain.

7. Menurut Bartram Johannes Otto Schrieke, pengaruh adalah bentuk dari suatu kekuasaan yang tidak dapat diukur kepastiannya.

8. Menurut Albert R. Roberts dan Gilbert, pengaruh adalah wajah kekuasaan yang diperoleh oleh orang saat tidak memiliki kewenangan untuk mengambil keputusan.

9. Menurut Jhon Miller, pengaruh adalah komoditi berharga dalam dunia politik Indonesia.

Dari pengertian-pengertian yang ada diatas naka dapat disimpulkan bahwa pengaruh merupakan sesuatu yang tak bias dilihat bentuknya namun bias dirasakan keberadaan dan dampaknya, baik dampak buruk atau baik dalam aktivitas manusia di kehidupan sehari - hari.

\section{MODEl YANG DiUSULKAN}

\section{A. Peluang dalam menghadapi Inovasi Disrutif pada Era Socienty 5.0}

Inovasi desruptif adalah fenomena munculnya teknologi atau tren baru di tengah tengah masyarakat yang menggeser tren atau kebiasaan lama. Inovasi desruptif terus berkembang dengan pesat dikarenakan potensi dan nilai manfaatnya yang begitu besar dirasakan masyarakat. Inovasi disruptif kerap mencetuskan ide mengenai produk atau layanan baru yang tidak terpikirkan dan berdaya guna tinggi. Manfaat-manfaat yang dirasakan dari inovasi desruptif 
diantaranya efisiensi dan efektifitas. Kemudian Produk yang dihasilkan melalui inovasi biasanya memiliki kualitas yang lebih baik dibandingkan dengan produk sebelumnya yang dibuat secara konvensional. Pada umumnya, akibat disrupsi semua hal menjadi serba lebih baik, mulai dari lebih hemat waktu hingga lebih efisien. Dengan manfaat-manfaat tersebut menggambarkan betapa besarnya peluang bagi segala pihak yang mampu menghadapi Inovasi Desruptif di era society 5.0.

Akademi Militer sebagai penyelenggara pendidikan pertama yang menghasilkan output perwira TNI Angkatan Darat dituntut untuk membentuk postur perwira yang profesional dan berkarakter. Dengan melihat input peserta didik Akademi Militer yang merupakan lulusan SMA sederajat, adalah merupakan generasi yang sangat terikat dengan teknologi dan informasi dalam kehidupan sehari-hari. Hal ini akan menimbulkan potensi dan peluang tersendiri bagi Akademi militer untuk menjalankan pendidikan pada era society 5.0. Pada era society 5.0 manusia sebagai komponen utama yang memiliki nilai-nilai baru dalam perkembangan teknologi sehingga sistem pendidikan harus dirubah seiring dengan berlangsungnya proses globalisasi dan banyaknya temuan baru dibidang teknologi komunikasi dan informasi. Perwujudan pemanfaatan peluang menghadapi Inovasi Desruptif oleh Akademi Militer dilaksanakan dengan penggunaan teknologi yang modern dalam pembelajaran Taruna, sehingga secara efektif dan efisien mampu memenuhi tujuan pembelajaran. Hal ini dikarenakan teknologi yang berkembang telah memudahkan penerimaan materi pelajaran oleh Taruna yang notabene adalah generasi yang sarat akan penggunaan teknologi dalam sehari-harinya. Akademi Militer terus berbenah dan menjalankan pembaruan yang positif di segala sektor untuk memanfaatkan peluang dalam menghadapi Inovasi Desruptif di era Society 5.0

\section{B. Tantangan dalam menghadapi Inovasi Disrutif pada Era Socienty 5.0}

J Pada era society 5.0 terjadi gap yang semakin besar antar generasi. Perbedaan generasi ini telah mengantarkan kehancuran yang besar pada nilai-nilai dan kebiasaan yang telah bertahan lama pada waktu lama untuk kemudian menjadi hilang atau tidak digunakan sama sekali pada masa yang akan datang. Dimana nilai-nilai tersebut tidak sedikit merupakan nilai-nilai positif yang keberadaannya harus tetap eksis dan berdampingan dengan perkembangan teknologi yang timbul di era inovasi desruptif. Perkembangan yang sangat pesat pada bidang teknologi dan informasi juga menuntut manusia untuk mampu beradaptasi secara cepat dan memiliki keterampilan yang mumpuni dalam memnafaatkan ilmu pengetahuan dan teknologi. Ini merupakan tantangan karena pada masyarakat masih terdapat labelling terhadap suatu golongan seperti ageism dan racism yang menghambat kemajuan dari masing-masing individu karena generalisir terhadap suatu golongan maupun tidak diberinya kesempatan untuk berkembang. Disinilah peran pendidikan dibutuhkan, Indonesia membutuhkan kurikulum, tenaga pengajar, dan juga fasilitas yang mumpuni dalam menciptakan peserta didik yang memiliki kemampuan dalam penyelesaian masalah, berpikir kritis, kreativitas, kepemimpinan,kolaborasi, kecerdasan emosional, dan negosiasi. Pendidikan juga dituntut untuk tetap menanamkan nilai-nilai luhur Bangsa Indonesia yang semakin tergerus oleh globalisasi. Hal ini dibutuhkan agar manusia Indonesia mampu bertahan dan memanfaatkan era society 5.0 secara optimal dan tetap memiliki budi pekerti luhur guna mewujudkan kemajuan bagi bangsa Indonesia.

Akademi Militer sebagai penyelenggara pendidikan pertama yang menghasilkan output perwira TNI Angkatan Darat dituntut untuk membentuk postur perwira yang profesional dan berkarakter. Dengan melihat input peserta didik Akademi Militer yang merupakan lulusan SMA sederajat, adalah merupakan merupakan generasi yang sangat terikat dengan teknologi dan informasi dalam kehidupan sehari-hari. Hal ini akan menimbulkan potensi dan tantangan tersendiri bagi Akademi militer untuk menjalankan pendidikan yang mampu memaksimalkan potensi dan menghadapi tantangan inovasi disruptif pada era society 5.0. 
Pada era society 5.0 manusia sebagai komponen utama yang memiliki nilai-nilai baru dalam perkembangan teknologi sehingga sistem pendidikan harus dirubah seiring dengan berlangsungnya proses globalisasi dan banyaknya temuan baru dibidang teknologi komunikasi dan informasi..

\section{Kendala dalam menghadapi Inovasi Disrutif pada Era Socienty 5.0}

Terdapat beberapa kendala di dalam proses adaptasi terhadap inovasi disruptif Di era society 5.0 seperti keterlambatan proses pemerataan perekonomian di Indonesia, tingkat illiterasi yang tinggi, perbedaan budaya dan tradisi, serta kondisi geografis Indonesia. Secara luas permasalahan terjadi secara serentak dengan fokus yang berbeda di setiap daerahnya. Pada bidang pendidikan, keadaan bangsa Indonesia saat ini berdampak besar terhadap kemampuan beradaptasi terhadap inovasi disruptif di era society 5.0 seperti belum meratanya pendidikan di Indonesia, belum mumpuni fasilitas yang dimiliki oleh penyelenggara pendidikan, sampai peserta didik yang masih memiliki tuntutan lain di bidang ekonomi. Hal ini membuat terjadi perbedaan kemampuan masing-masing individu satu dengan lainnya dalam menyesuaikan diri di era ini. Keadaan sosial di masyarakat juga berpengaruh terhadap pendidikan yang ada, sebagai contoh ageism yang kerap kali terjadi menyerang kelompok usia diluar usia produktif sehingga terdapat labelling bahwa kelompok usia diluar usia produktif tidak mampu untuk menunjukkan kemampuan dan keterampilannya di dalam era society 5.0. Age gap juga menjadi masalah tersendiri karena terdapat celah sosial yang besar antar generasi akibat adanya inovasi disruptif yang menghancurkan konformitas sosial yang ada.

Di Akademi Militer, dalam penyelenggaraan pendidikan tentu saja kultur dan tradisi militer tetap harus dipertahankan guna menciptakan perwira TNI-AD yang profesional dan militan. Namun pelestarian nilai kemiliteran ini juga berdampak negative dalam kemampuan dalam menghadapi inovasi disruptif di era society 5.0, sebagai contoh perilaku senioritas dan hierarkis dapat menekan kreatifitas seseorang dan menciptakan ketakutan sehingga timbul keengganan untuk mendapatkan atau menunjukkan keterampilan dan kemampuan yang dimiliki. Kendala apapun tentu bisa dihadapi dengan baik demi mewujudkan tujuan bangsa ini dengan cara merubah pemikiran dan meninggalkan kebiasaan yang sekiranya dapat menghambat proses beradaptasi tetapi dengan melestarikan nilai luhur para pendahulu. Kesadaran akan keadaan juga ditumbuhkan di dalam pendidikan di Akademi Militer sehingga mampu mengevaluasi diri dan mengejar ketertinggalan di era ini guna menjadi seorang perwira TNI-AD yang professional dan militant berlandaskan wawasan kebangsaan.

\section{Hambatan dalam menghadapi Inovasi Disrutif pada Era Socienty 5.0}

Dalam menciptakan sebuah pembaruan pasti akan ada hambatan dalam pelaksanaanya. Hambatan adalah hal yang wajar dan pasti akan muncul sebagai sebuah bagian dari proses untuk mencapai tujuan dari pembaruan tersebut. Hambatan yang muncul dapat berasal dari pencipta ide atau inovasi itu sendiri atau dari faktor-faktor lain seperti masyarakat atau non teknis. Ada berbagai faktor yang menghambat sebuah inovasi. Di antara adalah kurangnya sumber daya dan dukungan manajemen puncak, kurangnya anggaran, pemikiran yang terlalu jangka pendek dan tidak memiliki strategi dan visi jangka panjang, penghindaran risiko, budaya organisasi yang tidak mendukung ide-ide dan belajar hal-hal baru, ketakutan untuk berubah, kurangnya fokus, dan lain sebagainya.

Untuk mengatasi hambatan hal yang utama dibutuhkan adalah kreatifitas. Para pemimpin kreatif mendorong orang lain untuk meninggalkan pendekatan yang sudah ketinggalan zaman dan mengambil risiko yang seimbang. Mereka berpikiran terbuka dan inventif dalam memperluas gaya manajemen dan komunikasi mereka, terutama untuk terlibat dengan generasi baru yang menciptakan Inovasi Desruptif. Akademi Militer kini telah banyak menerapkan 
penggunaan teknologi dan Inovasi dalam pembelajaran Taruna guna menghadapi era society 5.0.Hambatan yang dialami Akademi Militer dalam menghadapi Inovasi Desruptif tersebut diantaranya adalah pemeliharaan produk teknologi yang digunakan. Penggunaan teknologi tentu membutuhkan perawatan dan pemeliharaan secara berkelanjutan untuk menjaga kualitas dan efektivitas dari produk inovasi tersebut. Kemudian konsistensi untuk terus mampu memaksimalkan penggunaan dari teknologi untuk kegiatan pembelajaran. Penggunaan teknologi oleh Akmil dalam pembelajaran Taruna harus dilaksanakan secara konsisten guna mencapai tujuan pembelajaran. Hambatan juga dapat timbul pengajar yang harus menyesuaikan modernisasi. Karena sebagian besar pengajar di Akademi Militer adalah generasi yang akrab dengan teknologi lama sehingga perlu penyesuaian dengan inovasi yang ada di Akademi Militer

\section{IMPLEMENTASI MODEL DAN PEMBAHASAN}

\section{A. Kondisi yang Diharapkan}

Kondisi yang diharapkan dari adanya fenomena Inovasi Disruptif di era society 5.0 ini adalah Sumber daya manusia Indonesia mampu meningkatkan kualitasnya dan selalu melakukan inovasi- inovasi sehingga melahirkan berbagai kreasi yang memberikan kontribusi bagi kemajuan lingkungan dan masyarakat umumnya. Untuk mencapai kondisi yang diharapkan tersebut, maka harus diawali dengan penerimaan masyarakat terhadap pembaruan-pembaruan dan inovasi yang semakin sering muncul. Selain itu, untuk menghadapi era society 5.0, setiap manusia diharapkan memiliki kompetensi yang dibutuhkan. Berdasarkan riset World Economic Forum (WEF) 2020, terdapat 10 kemampuan utama yang paling dibutuhkan untuk menghadapi era Revolusi Industri 4.0 dan sangat relevan dengan era society 5.0, yaitu bisa memecahkan masalah yang komplek, berpikir kritis, kreatif, kemampuan memanajemen manusia, bisa berkoordinasi dengan orang lain, kecerdasan emosional, kemampuan menilai dan mengambil keputusan, berorientasi mengedepankan pelayanan, kemampuan negosiasi, serta fleksibilitas kognitif.

Inovasi Desruptif tentu akan menghasilkan peluang dan tantangan. Oleh sebab itu, dengan penguasaan 10 kemampuan diatas kondisi yang diharapkan adalah setiap masyarakat mampu memaksimalkan potensi dan peluang dalam menhadapi inovasi desruptif di era 5.0 serta mampu mengatasi tantangan yang ada di dalamnya. Dengan memaksimalkan peluang yang terdapat pada inovasi-inovasi tersebut maka akan terwujud efektifitas dan efisiensi dalam berbagai aspek sehingga mendorong terciptanya tujuan untuk memajukan masyarakat. Dengan adanya Inovasi Disruptif dampak buruk yang dapat ditimbulkan adalah lengsernya budaya atau nilai-nilai yang telah ada sebelumnya. Indonesia adalah negara yang sangat kaya akan nilai-nilai budaya dan tradisi baik yang telah eksis sejak lama. Munculnya Inovasi Disruptif diharapkan tidak menggeser nilai-nilai budaya baik yang sudah ada. Perkembangan inovasi dan teknologi harus mampu berjalan beriringan dengan eksistensi kultur dan budaya yang telah ada di Indonesia.

\section{B. Upaya-Upaya mengatasi}

Inovasi disruptif menginisiasi lahirnya model bisnis baru dengan strategi lebih inovatif dan disruptif. Cakupan perubahannya luas mulai dari dunia bisnis, perbankan, transportasi, sosial masyarakat, hingga pendidikan. Era ini akan menuntut kita untuk berubah atau punah. Pada era society 5.0, masyarakat dituntut untuk dapat memecahkan berbagai masalah dan tantangan sosial dengan menggabungkan inovasi revolusi industri 4.0 seperti artificial intellegence, Internet of Things (IoT), robotik, dan big data di setiap aspek kehidupan. Oleh sebab itu, akan tercipta suatu nilai baru dan kemajuan akan terus berkembang seiring berjalannya waktu. Jika ingin terus bersaing, maka meningkatkan kemampuan sendiri dan staf adalah salah satu hal yang tidak terhindarkan. 
Jika tidak atau jika hanya menunggu, sudah pasti gelombang inovasi disruptif ini akan melanda secara perlahan, bertahap, dan berlanjut. Jika tidak punya rencana antisipasi dan kemampuan untuk beradaptasi, bersiaplah untuk tersingkir dan terpinggirkan tergerus arus inovasi yang mengganggu ini.

Ada beberapa kiat dalam menghadapi inovasi disruptif pada era society 5.0 . Yang pertama adalah selalu mengikuti perkembangan teknologi. Karena diketahui bahwa inovasi disruptif ini selalu berkaitan dengan teknologi. Teknologi yang terbaru dan terus ter-update. Dalam situasi pesaingan yang ketat ini, teknologi menjadi salah satu yang tidak dapat diabaikan. Jika terlambat menerapkan teknologi, perlahan-lahan hanya akan menjadi pengikut dan lamakelamaan akan terpinggirkan. Yang kedua adalah dengan menjadi manusia produktif. Dunia bergerak secara cepat. Kemungkinan di era inovasi disruptif terpelanting dari kompetisi karena lamban merespons inovasi atau menjadi penguasa baru. Jadi, orang bisa menjadi pecundang atau pemenang bergantung pada tingkat produktivitas keseharian. Bagaimana menjadi produktif dalam kehidupan sehari-hari. Terdapat berbagai cara agar bisa menjadi manusia produktif. Karena hanya dengan menjadi manusia produktif, seseorang akan mencapai sukses. Menjadi pribadi produktif adalah kunci awal bertahan di tengah era inovasi yang disruptif ini. Mereka yang tak cepat berubah dengan usaha- usaha produktif akan tersisihkan.

Sebagai contoh nyata hukum inovasi disruptif, hadirnya aplikasi online yang merambah setiap aspek kehidupan masyarakat, khusunya bidang pendidikan. Bahkan operasional pendidikan sekarang menggunakan internet sebagai basisnya mulai dari buku pelajaran sampai pertemuan kegiatan belajar mengajar. Sedang aplikasi pendidikan berbasis online atau yang biasa disebut e- learning membuat sedikit kendala tenaga pendidik dan peserta didik yang terbiasa melaksanakan kegiatan belajar mengajar secara konvensional. Pelaksana pendidikan kini berada di ujung tanduk bila mereka tidak beradaptasi dan berinovasi produktif dalam mengajar bagi pendidik serta berperan aktif dalam pembelajaran bagi peserta didik. Salah satu contoh inovasi disruptif di era society 5.0 pada bidang pendidikan adalah aplikasi Ruangguru. Saat awal didirikan pada tahun 2014, belum begitu banyak yang mengenal Ruangguru, sebuah alternatif pembelajaran online di Indonesia. Menurut Global System for Mobile Communications, gojek dimulai dengan sekitar 13.000 pengguna pada tahun 2014. Sampai akhir tahun 2017 , pengguna Ruangguru sudah mencapai 6.300 .000 orang. Dilansir dari situs resmi Ruangguru, semakin mantapnya posisi Ruangguru di pasar pembelajaran online, membuat Ruangguru melebarkan platformnya antara lain meluncurkan Sekolah Online Ruangguru Gratis yang telah dimanfaatkan oleh lebih dari 10 juta siswa dari Sabang sampai Merauke, memberikan akses kuota internet gratis selama mengakses layanan Ruangguru bekerja sama dengan berbagai penyedia layanan telekomunikasi, membuka 250 modul pelatihan guru yang telah diakses lebih dari 200.000 guru, mempersembahkan puluhan ribu beasiswa belajar kepada anak-anak tenaga medis, anak kurang mampu di daerah 3T, dan anak yatim piatu di ratusan panti asuhan di 34 provinsi. Hingga Desember 2020, Ruangguru telah melayani lebih dari 22 juta pengguna di seluruh Indonesia. Angka ini meningkat sebanyak 7 juta pengguna atau setara dengan 46\% dibandingkan dengan data per akhir Desember 2019.

\section{Ruangguru: registered students}

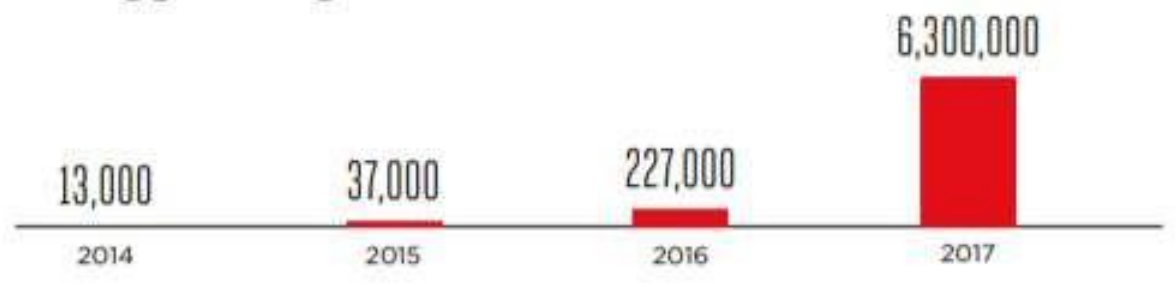

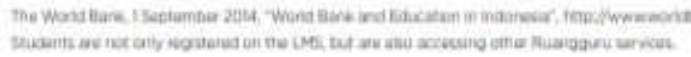

Gambar 1.Perkembangan pengguna yang terdaftar di Ruangguru 
Sama halnya dengan pelaksanaan pembelajaran di Akademi Militer yang saat ini menggunakan inovasi disruptif seperti e-learning yang memuat bahan ajar diberikan dalam bentuk soft file, jadwal pelajaran, dan evaluasi hasil belajar dalam satu akun portal e-learning Akademi Militer yang dapat diakses kapanpun dan dimanapun.

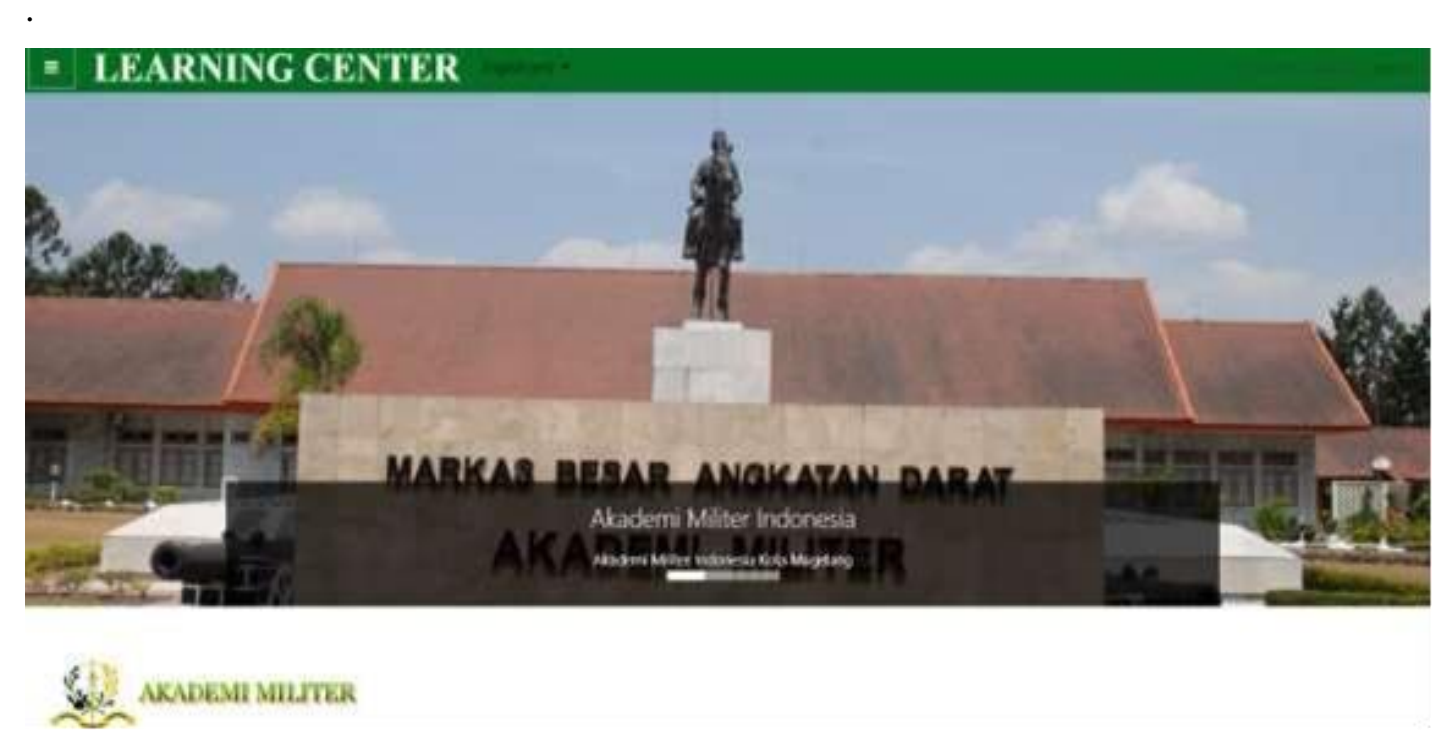

Gambar 2. Website e-learning Akademi Militer

Selain itu pelatihan keterampilan sebagai seorang prajurit di Akademi Militer juga telah mengalami perubahan akibat inovasi disruptif guna beradaptasi dalam era society 5.0 seperti halnya simulasi tembak yang menggunakan recoildop laser, augmented reality sandbox, dan navigasi darat menggunakan GPS guna meningkatkan kemampuan taruna dalam kemampuan teknis dan taktis bertempur untuk mencapai tugas pokok sebagai perwira TNI-AD. Pada era society 5.0 manusia dituntut untuk selalu produktif. Manusia yang produktif harus mempunyai pemikiran yang cerdas dan kreatif. Pikiran dan mental produktif membutuhkan manusia keluar dari zona nyaman dengan terus menyibukkan diri pada sesuatu yang baru dalam kesehariannya. Mental produktif keseharian menegasikan ketakutan akan kegagalan serta menjadikan diri sebagai manusia yang mampu menangkap setiap momen peluang dan mengeksekusinya.

Berdasarkan riset World Economic Forum (WEF) 2020, terdapat 10 kemampuan utama yang paling dibutuhkan untuk menghadapi era Revolusi Industri 4.0, yaitu bisa memecahkan masalah yang komplek, berpikir kritis, kreatif, kemampuan memanajemen manusia, bisa berkoordinasi dengan orang lain, kecerdasan emosional, kemampuan menilai dan mengambil keputusan, berorientasi mengedepankan pelayanan, kemampuan negosiasi, serta fleksibilitas kognitif. 10 Kemampuan ini juga relevan dalam menghadapi Society 5.0. Dalam pengembangan pendidikan konsep pengetahuan dan kreativitas, bisa memanfaatkan model pembelajaran seperti discovery learning, project based learning, problem based learning, dan inquiry learning. Dari berbagai model tersebut mendorong perseta didik untuk membangun kreativitas serta berpikir kritis.

Akademi Militer sebagai institusi pendidikan calon perwira TNI-AD telah beradaptasi dengan memanfaatkan inovasi disruptif di era society 5.0 dengan menerapkan model pembelajaran diatas dalam program seperti open discussion tentang materi yang diberikan sehingga dapat menemukan solusi dengan beberapa alternatif solusi, case study yaitu pemberian kasus nyata yang kompleks sebagai konteks bagi para peserta didik untuk berpikir analitis dan kritis dalam menyelesaikan masalah, dan project design dimana pendidik akan memberikan suatu proyek kepada peserta didik untuk diselesaikan guna melatih kreatifitas dan tanggung jawab. Hal ini difasilitasi penggunaan media belajar yang aktual dengan melibatkan pengoperasian teknologi terkini guna mengoptimalkan hasil belajar dan latihan Taruna Akademi Militer. 
Dengan penerapan metode-metode diatas sebagai cara terbaik Akademi Militer memanfaatkan teknologi inovasi disruptif dalam era society 5.0 dengan tujuan peserta didik menjadi pribadi yang produktif, kreatif, dan berpikir kritis. Peserta didik juga dapat memilah hal apa saja yang harus diimplementasikan dan tidak pada dirinya dan lingkungan kerjanya kelak sebagai seorang perwira TNI-AD. Inilah hasil didik yang diharapkan oleh Akademi Militer yang memiliki kemampuan sempurna sebagai seorang pemimpin dan konseptor handal yang dapat diindikasikan dengan kemampuan beradaptasi secara cepat terhadap segala kondisi yang ada.

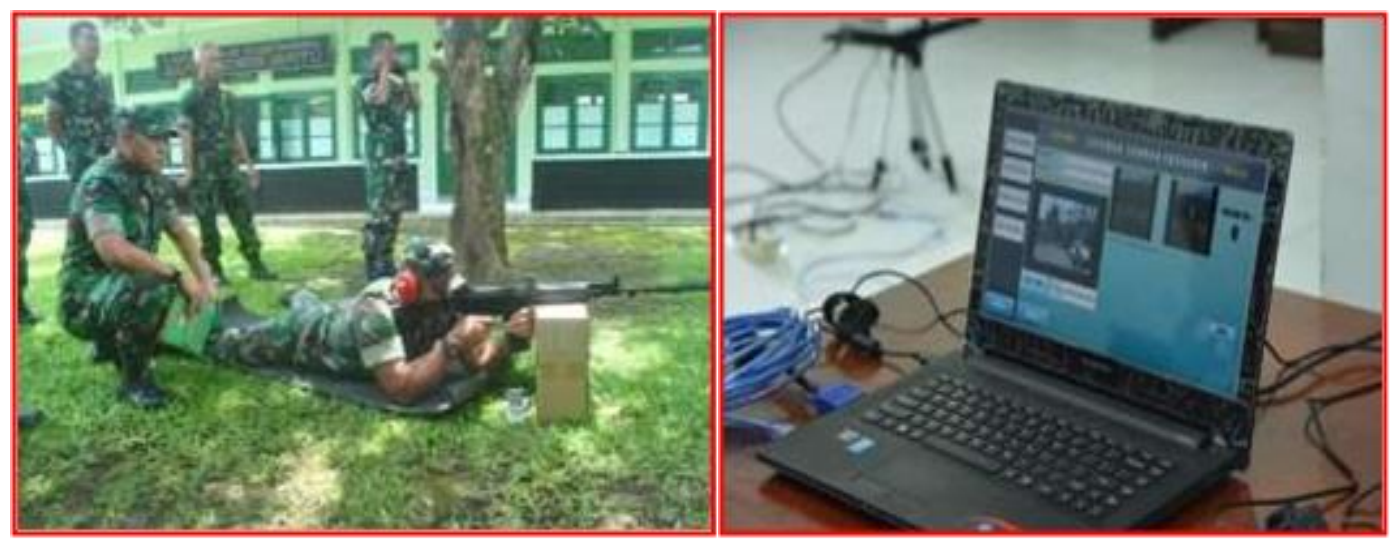

Gambar 3. Simulasi tembak yang menggunakan recoildop laser

\section{KESIMPULAN}

Inovasi disruptif adalah fenomena global yang sedang terjadi di era society 5.0 saat ini berkat penggunaan teknologi informasi dan komunikasi. Inovasi ini telah mengubah banyak perspektif dalam berbagai aspek kehidupan umat manusia, yang intinya memberi pilihan yang lebih menguntungkan bagi masyarakat. Oleh sebab itu, inovasi seperti ini tidak mungkin dihambat, mengingat perkembangan yang inovatif (innovative growth) merupakan salah satu pendorong bagi perkembangan peradaban manusia. Dengan munculnya fenomena inovasi disruptif di negara kita khususnya di lingkungan Pendidikan, harus mengikuti dengan cara memanfaatkan teknologi yang sedang berkembang. Karena dengan cara tersebut maka keuntungan dan manfaat akan didapatkan untuk meningkatkan kualitas pendidikan di Indonesia. Begitu juga sebaliknya, bila tetap menggunakan cara tradisional, tidak mau mengikuti perkembangan yang ada, maka akan tertinggal dengan yang lain. Yang akibatnya akan mengalami ketertinggalan dalam kualitas sumber daya manusia.

Untuk mendapatkan keuntungan dan kemanfaatan dengan adanya inovasi disruptif, harus mengasah diri dalam penggunaan teknologi, baik dalam mendapatkan informasi maupun pengoperasionalan teknologi tersebut. Teknologi sangat penting untuk dikuasai, karena dengan teknologi akan mendapatkan alternatif dalam melaksanakan pengajaran yang disesuaikan dengan kondisi yang ada guna mengoptimalkan hasil belajar. Dari kondisi itulah bisa mewujudkan hasil didik yang memiliki keterampilan unggul dan pribadi luhur.

Cara terbaik Akademi Militer dalam memanfaatkan inovasi disruptif di era society 5.0 adalah dengan mengintegrasikan inovasi disruptif dengan metode belajar yang dapat memberikan kemampuan menghadapi permasalahan kompleks dan memanfaatkan teknologi terkini dalam rangka meningkatkan kualitas peserta didik secara efektif dan efisien yang mampu beradaptasi dengan segala kondisi dengan tetap mempertahankan kultur kemiliteran dan jiwa patriotisme sebagai seorang prajurit TNI-AD. 


\section{UCAPAN TERIMA KASIH}

Ucapan terima kasih atas terbitnya naskah ini pada Seminar Nasional Sains Teknologi dan Inovasi Indonesia 2021 sebagai bagian kolaborasi/kerjasama penelitian antara Akademi Militer dengan Akademi Angkatan Udara.

\section{REFERENSI}

[1] Atsushi Deguchi, C. H. (2020). What Is Society 5.0. Society 5.0, 2.

[2] Fukuyama, M. (2018). Society 5.0: Aiming for a New Human-Centered Society. Japan Spotlight, 47.

[3] Hadad. (2017). Knowledge Economy: Characteristics and Dimensions . Management Dynamics in the Knowledge Economy, 3.

[4] Hamid, E. S. (2017). Disruptive Innovation: Manfaat Dan Kekurangan Dalam Konteks Pembangunan Ekonomi. Universitas Islam Indonesia,, 2.

[5] Jenkins, R. (2017). Robot Ethics 2.0: From Autonomous Cars to Artificial Intelligence. Oxford University Press, 13.

[6] Joseph L. Bower, C. (1995). Disruptive Technologies: Catching the wave . Academia, 43.

[7] Rustandi, D. (2020, Juni 22). Tantangan Disrupsi Teknologi Indonesia. Dipetik Oktober 18, 2021, dari www.dikti.kemdikbud.go.id: https://dikti.kemdikbud.go.id/highlight/tantangan-disrupsi-teknologi-indonesia/

[8] Yuniansari, N. (2018, Mei 20). Ruangguru: Accelerating Indonesia's educational outcomes. Dipetik Oktober 18, 2021, dari www.gsma.com: https://www.gsma.com/mobilefordevelopment/wp-content/uploads/2018/05/RuangguruAccelerating-Indonesia\%E2\%80\%99s-educational-outcomes.pdf 